JEL: C26, D24, Q16

Олександр Олійник', Віталій Макогон ${ }^{1}$ Віталія Міщенко ${ }^{1}$ Світлана Брік²

${ }^{1}$ Харківський національний аграрний університет ім. В. В. Докучаєва ${ }^{2}$ Національний технічний університет «Харківський політехнічний інститут»

Україна

\title{
ЕФЕКТИВНІСТЬ ВИТРАТ НА ВПРОВАДЖЕННЯ НОВИХ СОРТІВ I ГІБРИДІВ У РОСЛИННИЦТВІ
}

Мета. Мета статті - висвітлити результати дослідження, присвяченого розробиі підходів до оптимізації рівня витрат на впровадження нових сортів $i$ гібридів $y$ рослинництві, у тому числі за умов їх фінансування за рахунок позикового капіталу.

Методологія / методика / підхід. Спираючись на діалектичний метод пізнання, використали методи: абстрактно-логічний (систематизачія публікачій, присвячених проблемам агроінновачій $і$ кредитування аграрної галузі, теоретичні узагальнення та формулювання висновків), нелінійного кореляційно-регресійного аналізу (установлення залежності між інтенсивністю виробництва продукиії рослинництва та результатами функиіонування галузі), оптимізаційного моделювання (розробка інструментарію, що дозволяє визначити оптимальний обсяг кредиту в разі впровадження інноваџій).

Результати. Розроблено підхід, який ураховує агробіологічні, економічні та фінансові аспекти аграрної галузі, та дозволяе на етапі планування виробничого прочесу $i$ його фінансового забезпечення оцінити доцільність кредитного покриття витрат на впровадження інноваційного рімення; апробовано методичний інструментарій, який дозволяе визначити оптимальні величини витрат за різних умов $i$ форм фінансування, $a$ також оптимальну величину кредитного забезпечення, щз гарантує максимізацію прибутку з урахуванням очікуваного приросту урожайності за рахунок упровадження нових сортів $i$ гібридів.

Оригінальність / наукова новизна. Обгрунтовано підхід до визначення оптимального обсягу кредитного забезпечення впровадження інновачій, щчо, на відміну від традииійного, який трунтується на ефекті фінансового важеля, ураховує нелінійність витратних $i$ результативних показників функиіонування аграрної галузі, спричинену ефектом спадної віддачі.

Практична цінність / значущість. Застосування пропонованого до впровадження методичного підходу дозволяе визначити оптимальні величині виробничих витрат $i$ ïх кредитного покриття з урахуванням очікуваного приросту урожайності виробничтва, який забезпечує впровадження нового сорту або гібриду рослин.

Ключові слова: витрати, прибуток, інновачія, кредитування, позиковий капітал, закон спадної віддачі, регресія, економіко-математичне моделювання, урожайність, сорти $i$ гібриди.

Oleksandr Oliynyk ${ }^{1}$, Vitaliy Makohon ${ }^{1}$, Vitaliya Mishchenko ${ }^{1}$, Svitlana Brik ${ }^{2}$

${ }^{1}$ Kharkiv National Agrarian University named after V. V. Dokuchaev

${ }^{2}$ National Technical University «Kharkiv Polytechnic Institute»

Ukraine 


\section{COST EFFICIENCY FOR IMPLEMENTATION OF NEW VARIETIES AND HYBRIDS IN PLANT GROWING}

Purpose. The purpose of the article is to demonstrate the results of a study devoted to the development of approaches to optimizing the level of costs for the implementation of new varieties and hybrids in crop production, including under conditions of its financing through borrowed capital.

Methodology / approach. Based on the dialectical method of cognition, the abstract-andlogical method (systematization of the publications on agroinnovations and crediting of the agricultural sector, theoretical generalizations and conclusions), the nonlinear correlation and regression analysis (establishing the interdependence between the intensity of plant products production and the results of the functioning of the branch), optimization modeling (development of tools to determine the optimal amount of the credit in terms of innovation) were used.

Results. The approach has been developed that takes into account the agrobiological, economic and financial aspects of the agricultural branch and allows assessing the appropriateness of the credit covered expenses of implementing an innovative solution at the stage of planning the production process and its financial support; the methodological tools have been tested, which allow determining the optimal values of the costs under different conditions and forms of financing, as well as the optimal amount of credit support, which maximizes profits taking into account the expected increase in crop capacity due to the implementation of new varieties and hybrids.

Originality / scientific novelty. The approach to determining the optimal amount of credit support for innovation, which in contrast to the traditional one, that is based on the effect of the financial leverage, takes into account the nonlinearity of the cost and the efficiency indicators of the agricultural sector caused by the effect of diminishing returns.

Practical value / implications. The application of the proposed methodological approach allows determining the optimal values of the production costs and their credit coverage, taking into account the expected increase in productivity, which provides the implementation of a new variety or hybrid of plants.

Key words: costs, profit, innovation, crediting, borrowed capital, law of diminishing returns, regression, economic and mathematical modeling, crop capacity, varieties and hybrids.

Постановка проблеми. Стрімкі економічні трансформації, зростання попиту на продукти харчування, посилення конкуренції на аграрному ринку перетворили інноваційний процес у домінанту розвитку світового й вітчизняного сільського господарства. Не зменшуючи роль технологічних нововведень у забезпеченні продовольчої безпеки та експортного потенціалу країни, змушені констатувати деяку неузгодженість тенденцій інноваційних процесів та економічних інтересів агровиробників. Зокрема, практика «єдиного вікна», за якого разом із насінням і добривами виробник купує допоміжні послуги, спряє росту урожайності, але водночас призводить до перевищення оптимального рівня витрат i недоотримання прибутку. Тому особливої актуальності набувають питання оцінки впливу інноваційної діяльності сільськогосподарських підприємств на ефективність їх функціонування. Також, ураховуючи волатильність агарних ринків, яка негативно впливає на прибутковість агроформувань й обмежує їх фінансові можливості, слід зазначити, що вагомим стає дослідження взаємозв'язку результатів упровадження інновацій, зокрема нових сортів і гібридів, та кредитного 


\section{Agricultural and Resource Economics: International Scientific E-Journal} http://are-journal.com

забезпечення інвестицій в оновлення технології виробництва.

Аналіз останніх досліджень і публікацій. Дослідження методичного підгрунтя інноваційної діяльності суб'єктів господарювання засвідчило, що іiі теоретичний базис заклали у своїх працях J.Schumpeter, J. Dunning, R. Lucas. Водночас проблематику впровадження інновацій та їх вплив на економічний розвиток висвітлено в роботах таких авторів, як В. Asheim [1; 2], A. Isaksen [1], M. Gertler [2], E. Brynjolfsson, L. Hitt [3], P. Cooke [4; 5], K. Morgan [5], C. Dahlman [6], R. Nelson [6; 7], C. Edquist [8; 9], C. Freeman [10], S. Gu [10] B. Lundvall [12], V. Babenko та ін. [13]. Також питанням оцінки ефективності використання позикового капіталу сільськогосподарськими товаровиробниками приділено значну увагу в публікаціях таких дослідників, як С. Asante-Addo та ін. [14], L. Baráth та ін. [15], W. Czubak, P. Pawłowski [16], M. Garrone та ін. [17], J. Hadrich та ін. [18], I. Islam та ін. [19], I. Kravčáková Vozárová та ін. [20], L. Long та ін. [21], S. Mitra та ін. [22], O. Musshoff та ін. [23; 24], C. Turvey [25], О. Вовчак та ін. [26], О. Гафурова та ін. [27], І. Думанська [28], Л. Катан [29], О. Непочатенко та ін. [30], О. Олійник-Данн та ін. [31], О. Горох та ін. [31]. Незважаючи на наявний методологічний базис, нині майже відсутні публікації, у яких систематизовано досліджено питання взаємозв'язку ефективності виробничих витрат, напрямів підвищення їх ефективності за рахунок упровадження інновацій, а також кредитного забезпечення цього процесу.

Мета статті. Метою статті $\epsilon$ висвітлення результатів дослідження, присвяченого розробці підходів до оптимізації рівня витрат на впровадження нових сортів і гібридів у рослинництві, у тому числі за умов їх фінансування за рахунок позикового капіталу.

Виклад основного матеріалу дослідження. Загальновизнано, що підпорядкованість механізму формування витрат i результатів агарного виробництва закону спадної віддачі зумовлює найбільшу вживаність для апроксимації залежності врожайності продукції рослинництва від операційних витрат на одиницю посівів параболічної виробничої функції:

$$
Y_{10}=-a X^{2}+b X-c,
$$

де $Y_{10}-$ очікувана урожайність сільськогосподарської культури, ц/га;

$X$ - виробничі витрати, тис. грн/га.

Зважаючи на правила диференціального числення, функція (1) досягає свого максимуму при питомих виробничих витратах $(X)$, які слід вважати їх оптимумом і величину яких характеризує залежність:

$$
X=\frac{b}{2 a}
$$

Упровадження інновацій спричиняе трансформацію аналітичного виразу виробничої функції (1). Наприклад, ідеться про застосування нового гібрида, який має урожайність у $k$ разів вищу від середньої, досягнутої в попередньому періоді. Водночас вища ціна цього посівного матеріалу зумовлює збільшення вартості насіння, а, відповідно, і сумарних питомих витрат на $D n$ тис. грн/га. Таким чином, нова форма виробничої функції (1), має вигляд: 


$$
Y_{11}=\left(-a(X-D n)^{2}+b(X-D n)-c\right) \cdot k,
$$

де $Y_{11}$ - очікувана врожайність сільськогосподарської культури після застосування інноваційного заходу, ц/га;

$k$ - коефіцієнт, що характеризує зростання врожайності сільськогосподарської культури внаслідок інноваційного заходу, який дорівнює підсумку одиниці та відсотку приросту врожайності у вигляді десяткового дробу;

$D n$ - приріст витрат на насіння з розрахунку на 1 га, тис. грн.

У свою чергу, оптимум витрат після впровадження інновацій характеризує залежність:

$$
X=\frac{b}{2 a}+D n
$$

Апробація результатів функціонального аналізу дозволила оцінити вплив інновацій на ефективність виробництва зернових, технічних, плодових, овочевих і кормових культур та інших видів продукції рослинництва. Обмеження обсягів не дозволяють висвітлити в одній журнальній публікації всі отримані результати. Ураховуючи значення виробництва зерна для економічної і продовольчої безпеки держави більш детально зупинимося на результатах аналізу для цієї галузі. Установлено, що рівняння залежності врожайності пшениці від виробничих витрат на 1 га посівів сільськогосподарських підприємств Харківської області у 2016-2018 рр., яку графічно ілюструє наведений нижче рисунок, було таким:

$$
Y_{10}=-0,33 X^{2}+8,48 X-6,24,
$$

де $Y_{10}$ - урожайність пшениці, ц/га;

$X$ - виробничі витрати на 1 га зібраної площі, тис. грн.

Залежність (5), сформована на підставі опрацювання статистичних даних про витрати на виробництво пшениці та урожайності цієї культури у 246 сільськогосподарських підприємствах Харківської області, має високий рівень статистичної надійності (коефіцієнт детермінації $\left(R^{2}\right)$ дорівнює 0,9328 , розрахункове значення коефіцієнта Фішера $\left(F_{p}\right)-61,4 \in$ вищим від його табличного значення $\left(F_{\text {табл. }}\right)$, яке дорівнює 8,5$)$. При цьому під час побудови цієї статистичної моделі за багаторічними даними цілком очікуваним $є$ вплив на витратні показники інфляційних процесів у роки, наступні після першого року дослідження. Так, згідно з даними Держаної служби статистики України, індекс цін на продукцію нафтопереробки у грудні 2017 р. по відношенню до аналогічного періоду 2016 р. становив 125,1\%, а в грудні 2018 р. - до грудня 2017 pp. 99,5\%. Натомість індекс цін виробників хімічних речовин і хімічної продукції, у тому числі мінеральних добрив та засобів захисту рослин, у грудні 2017 р. по відношенню до грудня 2016 р. становив 121,9\%, у грудні 2018 р. до грудня 2017 р. становив 107,7\%. Отже, слід констатувати уповільнення інфляції витрат у 2018 р. порівняно з 2017 р., а також суттєве зниження іiі темпів порівняно із 2014-2015 pр. Таким чином, зважаючи на необхідність урахування поступово спадаючого впливу інфляційних процесів витрати за окремими статтями витрат для досліджуваних господарств було збільшено на 
індекс цін на спожити матеріальні ресурси 3 диференціацією за їх номенклатурою.

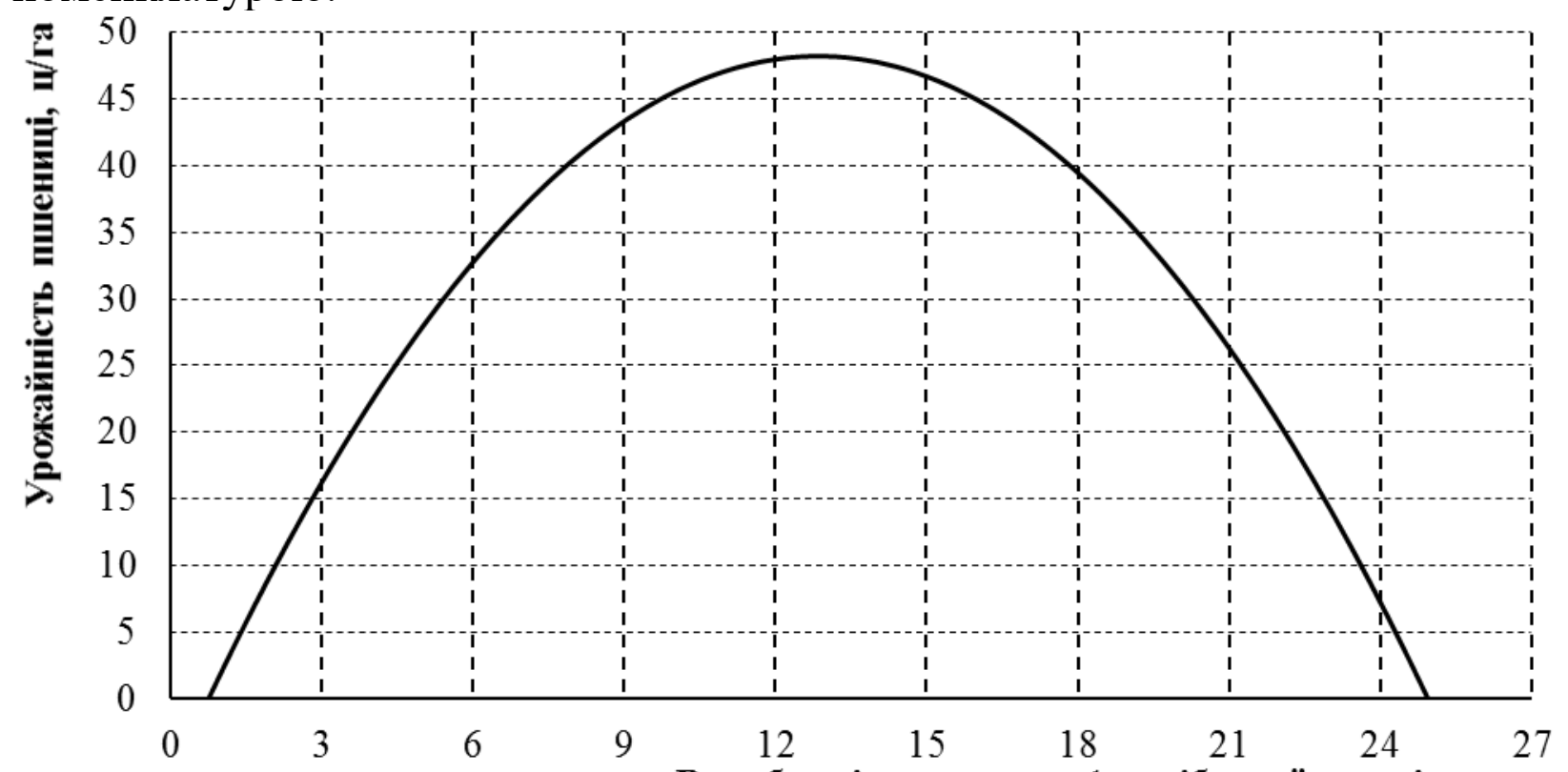

Виробничі витрати на 1 га зібраної площі, тис. грн.

Рис. 1. Залежність урожайності пшениці від виробничих витрат на 1 га зібраної площі в сільськогосподарських підприємствах Харківської області у 2016-2018 pp.

Джерело: результати власних розрахунків авторів.

Беручи до уваги мету дослідження, припустимо, що впроваджують гібрид 3 урожайністю, на $20 \%$ вищою від середньої в сільськогосподарських підприємствах Харківської області у 2016-2018 рр., ціна на який на 25 \% вища від ії значення в досліджуваному періоді. Значення коефіцієнта $k$ дорівнює 1,2 $(1+20 / 100=1,2)$. У свою чергу, ураховуючи, що середня ціна на насіння пшениці у 2016-2018 рр. становила 4031,74 грн/т, посівна одиниця впроваджуваного гібрида коштуватиме 5039,70 грн/т $(4031,74 \times 1,25)$. Оскільки, згідно 3 типовими технологічними картами, середня норма висіву для озимої пшениці становить 0,2 т/га [33], очікуване зростання виробничих витрат на 1 га ії посівів $(D n)$ дорівнюе 0,2 тис. $(0,2 \cdot(5039,70-4031,74) / 1000=0,2 \cdot 1007,96 / 1000=0,201 \approx 0,2)$. Отже, функція залежності врожайності пшениці від виробничих витрат на одиницю її посівів після впровадження нового гібрида матиме вигляд:

$$
\begin{gathered}
Y_{11}=\left(-0,33(X-0,2)^{2}+8,48(X-0,2)-6,24\right) \cdot 1,2= \\
=-0,40 X^{2}+10,33 X-9,54,
\end{gathered}
$$

де $Y_{11}$ - очікувана урожайність сільськогосподарської культури після застосування інноваційного заходу, ц/га.

Аналіз розбіжності технологічних оптимумів витрат функцій (5) і (6), яка дорівнювала 0,2 ц/га, підтвердив результати функціонального аналізу (табл. 1). Таким чином, впровадження аналізованої інновації за умов дотримання технологічного підходу під час планування рівня інтенсивності виробництва забезпечує зростання максимально досяжної врожайності на $22,8 \%$. 
Констатуючи позитивні результати інноваційного процесу, не можна залишити поза увагою його кон'юнктурні наслідки. Зокрема, збільшення обсягів виробництва та пропозиції зерна пшениці призводить до уповільнення росту цін на нього, тому цілком можливим $є$ зниження прибутковості виробництва й збуту зерна пшениці на фоні зростання обсягів його виробництва.

Таблиия 1

Вплив інновацій на оптимальну інтенсивність і максимальну врожайність пшениці в сільськогосподарських підприємствах Харківської області y 2016-2018 pp.

\begin{tabular}{|l|c|c|c|}
\hline \multirow{2}{*}{\multicolumn{1}{|c|}{ Показник }} & \multicolumn{2}{|c|}{ Технологія } & Відхи- \\
\cline { 2 - 4 } & фактична & $\begin{array}{c}\text { при впровадженні } \\
\text { нового гібрида }\end{array}$ & $\begin{array}{c}\text { лення } \\
(+;-)\end{array}$ \\
\hline Технологічний оптимум витрат, тис. грн/га & 12,9 & 13,1 & 0,2 \\
\hline $\begin{array}{l}\text { Урожайність при витратах на рівні } \\
\text { технологічного оптимуму, тис. грн/га }\end{array}$ & 48,2 & 59,2 & 11,0 \\
\hline
\end{tabular}

Джерело: результати власних розрахунків авторів.

Отже, нагальною є потреба оцінки впливу кон'юнктурних чинників на результативність інноваційного процесу. Для цього, помноживши праву частину рівняння (1) на значення ціни реалізації $(p)$ і віднявши від неї величину питомих витрат $(X)$, сформовано залежність фінансової результативності технологій виробництва продукції рослинництва від питомих витрат:

$$
Y_{20}=p \cdot\left(-a X^{2}+b X-c\right) \cdot p-X
$$

де $Y_{20}$ - очікувана маса прибутку на 1 га посівів сільськогосподарської культури, тис. грн/га.

Ураховуючи міркування, які стали підгрунтям формування залежності (2), установлено, що прибутковий оптимуму витрат для залежності (7) характеризує рівняння:

$$
X=\frac{b}{2 a}-\frac{1}{2 a p}
$$

Далі, трансформувавши рівняння (3) у формулу залежності прибутку від питомих витрат після впровадження інноваційного рішення, визначено іi аналітичну форму:

$$
Y_{21}=\left(-a(X-D n)^{2}+b(X-D n)-c\right) \cdot k \cdot p-X
$$

де $Y_{21}$ - очікувана маса прибутку на 1 га посівів сільськогосподарської культури, після застосування інноваційного заходу, тис. грн/га;

$p$ - реалізаційна ціна 1 ц зерна пшениці, тис. грн/ц.

Прибутковий оптимум витрат після впровадження інновацій характеризує залежність:

$$
X=\frac{b}{2 a}-\frac{1}{2 a p k}+D n
$$

Наступним кроком наукового пошуку стало дослідження впливу інновацій на прибутковість виробництва зерна пшениці. Вихідним прийнято положення, що при середній ціні реалізації пшениці сільськогосподарськими підприємствами Харківської області у 2016-2018 рр. 312,21 грн/ц залежність 
прибутку від реалізації зерна пшениці від питомих виробничих витрат характеризує рівняння:

$$
\begin{gathered}
Y_{20}=\left(-0,33 X^{2}+8,48 X-6,24\right) \cdot 0,312-X= \\
=-0,10 X^{2}+1,65 X-1,95,
\end{gathered}
$$

де $Y_{20}$ - очікувана маса прибутку на 1 га посівів пшениці, тис. грн.

Залежність прибутку від реалізації зерна пшениці від питомих виробничих витрат після впровадженням нового гібрида є такою:

$$
\begin{gathered}
Y_{21}=\left(-0,40 X^{2}+10,49 X-9,54\right) \cdot 0,312-X= \\
=-0,12 X^{2}+2,22 X-2,98,
\end{gathered}
$$

де $Y_{21}$ - очікувана маса прибутку на 1 га посівів пшениці після застосування інноваційного заходу, тис. грн.

Спираючись на методичні підходи до визначення прибуткового оптимуму витрат до та після впровадження інновації, які аналітично описують рівняння (8) i (10), визначено, що за умов переходу до використання нового гібрида i дотримання маржиналістичного підходу до визначення оптимального планового рівня витрат, останній має бути підвищено з 8,0 до 9,0 тис. грн/га, що забезпечить приріст маси прибутку на 2,41 тис. грн/га (табл. 2).

Таблиия 2

\section{Вплив інновацій на оптимальну інтенсивність і максимальну}

результативність виробництва зерна пшениці в сільськогосподарських підприсмствах Харківської області у 2016-2018 рр.

\begin{tabular}{|l|c|c|c|}
\hline \multicolumn{1}{|c|}{ Показник } & \multicolumn{2}{|c|}{ Технологія } & $\begin{array}{c}\text { Відхи- } \\
\text { лення } \\
(+;-)\end{array}$ \\
\cline { 2 - 4 } & фактична & $\begin{array}{c}\text { при впровадженні } \\
\text { нового гібриду }\end{array}$ & $\begin{array}{c}\text { (1) } \\
\text { Оптимум витрат, тис. грн/га } \\
\text { технологічний }\end{array}$ \\
\hline $\begin{array}{l}\text { прибутковий } \\
\text { Урожайність при витратах на рівні, тис. грн/га } \\
\text { технологічного оптимуму }\end{array}$ & 8,0 & 9,0 & 1,0 \\
\hline прибуткового оптимуму & 48,2 & 59,2 & 11,0 \\
\hline $\begin{array}{l}\text { Прибуток при витратах на рівні, тис. грн/га } \\
\text { технологічного оптимуму }\end{array}$ & 2,15 & 51,4 & 11,3 \\
\hline прибуткового оптимуму & 4,63 & 5,06 & 2,91 \\
\hline
\end{tabular}

Джерело: результати власних розрахунків авторів.

Хоча максимальна очікувана врожайність при маржиналістичному підході до визначення оптимального планового рівня витрат є на 7,8 ц/га нижчою, ніж у разі дотримання під час його визначення підходу, який забезпечує максимізацію врожайності, маса прибутку на одиницю посівів пшениці за першого підходу є на 1,98 тис. грн/га більшою, ніж за другого. Отже, слід констатувати більш ніж потрійну окупність приросту витрат, зумовленого змінами в технології виробництва, що формує позитивний імідж інвестицій у такі технологічні інновації. Незважаючи на те, що вплив логістичних $\mathrm{i}$ маркетингових чинників (більші витрати на збирання та перевезення до місць зберігання, зниження цін 3 метою стимулювання збуту тощо) стримуватиме 
зростання прибутковості, подібні технологічні рішення цілком очікувано користуються попитом, що, у свою чергу, актуалізує питання їх фінансової підтримки. Також залучення позикових коштів для фінансування інвестиційних вкладень на платній основі впливає на величину оптимуму витрат i ïx окупність.

Для підтвердження цієї думки рівняння (7) трансформовано з урахуванням припущення щодо використання власних і позикових джерел фінансування витрат. Для цього $X$ було замінено змінними $V$ i $Z$, які позначають виробничі витрати, профінансовані за рахунок власного обігового та позикового капіталу відповідно. Ураховуючи платність користування позиковими коштами, фінансовий результат зменшено на добуток відсоткової ставки $(p s)$ на величину витрат на 1 га посівів, фінансованих за рахунок позикового капіталу $(Z)$. Отже, функція залежності прибутку від питомих витрат до впровадження інновації (7) набула вигляду:

$$
Y_{30}=\left(-a(V+Z)^{2}+b(V+Z)-c\right) \cdot p-(V+Z)-Z \cdot p s,
$$

де $V$ - виробничі витрати на 1 га посівів сільськогосподарської культури, фінансовані за рахунок власних джерел, тис. грн/га;

$Z$ - виробничі витрати на 1 га посівів сільськогосподарської культури, фінансовані за рахунок позикового капіталу, тис. грн/га.

Водночас залежність прибутку від питомих витрат, фінансованих за рахунок власних i позикових коштів, після впровадження інновації характеризує рівняння:

$$
\begin{gathered}
Y_{31}=\left(-a(V+Z-d N)^{2}+b(V+Z-d N)-c\right) \cdot k \cdot p- \\
-(V+Z)-Z \cdot p s
\end{gathered}
$$

Ураховуючи аналітичні залежності (13)-(14) і значення середньої відсоткової ставки за кредити, залучені досліджуваними сільськогосподарськими підприємствами, яка в аналізованому періоді дорівнювала 19,0\%, виробничу функцію залежності прибутковості виробництва зерна пшениці сільськогосподарськими підприємствами Харківської області від питомих витрат, фінансованих за рахунок власних i позикових коштів у 2016-2018 рр. характеризує рівняння:

$$
\begin{aligned}
Y_{30} & =-0,10(V+Z)^{2}+1,65(V+Z)-0,19 Z-1,95= \\
& =-0,10(V+Z)^{2}+1,65(V+0,88 Z)-1,95,
\end{aligned}
$$

де $Y_{30}$ - очікувана маса прибутку на 1 га посівів пшениці за умов їх фінансування з власних і позикових джерел, тис. грн.

Аналогічна залежність після впровадженням нового гібрида описує функція:

$$
\begin{aligned}
Y_{31}= & -0,12(V+Z)^{2}+2,22(V+Z)-0,19 Z-2,98= \\
& =-0,12(V+Z)^{2}+2,22(V+0,91 Z)-2,98,
\end{aligned}
$$

де $Y_{31}$ - очікувана маса прибутку на 1 га посівів пшениці після застосування інноваційного заходу за умов їх фінансування 3 власних i позикових джерел, тис. грн. 
Згідно з правилами диференціального числення, функції (15)-(16) мають окремі прибуткові оптимуми витрат, фінансованих за рахунок власних або позикових коштів. Аналітичний вираз для розрахунку оптимумів витрат, фінансованих за рахунок виключно власних коштів до і після впровадження інновацій буде таким:

$$
\begin{gathered}
V=\frac{b}{2 a}-\frac{1}{2 a p}-Z \\
V=\frac{b}{2 a}-\frac{1}{2 a p k}+d N-Z
\end{gathered}
$$

Для оптимумів витрат, фінансованих за рахунок позикових коштів, до i після впровадження інновацій слід застосовувати такі формули:

$$
\begin{gathered}
Z=\frac{b}{2 a}-\frac{1}{2 a p}-\frac{p s}{2 a p}-V, \\
Z=\frac{b}{2 a}-\frac{1}{2 a p k}-\frac{\mathrm{ps}}{2 a p k}+d N-V
\end{gathered}
$$

Формули (19)-(20) свідчать, що оптимум витрат, фінансованих за рахунок власних і позикових коштів, що максимізує прибуток, є незмінним за будьякого співвідношення власних і позикових коштів, тобто не залежить від структури джерел фінансування витрат. При цьому абсолютна величина прибутку зменшується прямо пропорційно до зростання частки позикових коштів і відсотка за їх користування. Це спричиняє цілком очікувані наслідки, а саме - сталість зниження оптимуму витрат пропорційно до зростання відсоткової ставки за кредит. Отже, і до впровадження нового гібрида, і після цього перехід до змішаного фінансування витрат призводить до зниження прибуткового оптимуму на 0,9 тис. грн/га (табл. 3 ).

Таблиия 3

Вплив джерел фінансування інновацій на оптимальну інтенсивність й очікувану результативність виробництва зерна пшениці сільськогосподарськими підприсмствами Харківської області у 2016-2018 рр. (умовні дані)

\begin{tabular}{|l|c|c|c|c|}
\hline \multicolumn{1}{|c|}{ Показник } & \multicolumn{2}{|c|}{$\begin{array}{c}\text { Фактична технологія } \\
\text { виробницта }\end{array}$} & \multicolumn{2}{|c|}{$\begin{array}{c}\text { Після впровадження } \\
\text { нового гібрида }\end{array}$} \\
\cline { 2 - 5 } & $\begin{array}{c}\text { власні } \\
\text { кошти }\end{array}$ & $\begin{array}{c}\text { позикові } \\
\text { кошти }\end{array}$ & $\begin{array}{c}\text { власні } \\
\text { кошти }\end{array}$ & $\begin{array}{c}\text { позикові } \\
\text { кошти }\end{array}$ \\
\hline Прибутковий оптимум витрат, тис. грн/га & 8,0 & 7,1 & 9,0 & 8,1 \\
\hline $\begin{array}{l}\text { Урожайність при витратах на рівні } \\
\text { прибуткового оптимуму, ц/га }\end{array}$ & 40,1 & 37,3 & 51,4 & 48,6 \\
\hline $\begin{array}{l}\text { Прибуток при витратах на рівні } \\
\text { прибуткового оптимуму, тис. грн/га } \\
\text { за умов самофінансування }\end{array}$ & 4,63 & $\mathrm{X}$ & 7,04 & $\mathrm{X}$ \\
\hline $\begin{array}{l}\text { фінансування за рахунок позикових } \\
\text { коштів }\end{array}$ & $\mathrm{X}$ & 3,20 & $\mathrm{X}$ & 5,42 \\
\hline
\end{tabular}

Джерело: результати власних розрахунків авторів.

Досить цікавим $є$ аналіз впливу на формування фінансових результатів трансформацій у технології виробництва й структурі джерел його фінансування. Як контрольний випадок узято ситуацію, коли 
сільськогосподарське підприємство при традиційній технології фінансує виробничі витрати за рахунок власних коштів; установлено, що за оптимуму витрат, рівному 8,0 тис. грн/га, максимально досяжний прибуток становить 4,63 тис. грн/га. Водночас перехід до змішаного фінансування при старій технології виробництва зумовлюе зниження оптимуму витрат на 11,3 \% і за умов стовідсоткового кредитного покриття виробничих витрат призводить до зниження прибутку порівняно з контрольним випадком на 30,9 \%.

Проте за умов, що для фінансування витрат використовують виключно позикові кошти й при цьому товаровиробник застосовує новий гібрид, виявлено зростання оптимуму витрат порівняно з контрольним випадком на 100 грн/га при одночасному прирості прибутку на 790 грн/га, або на 17,1\%. Отже, за гіпотетичних вихідних умов застосування гібрида із ціною, на 25 \% вищою від фактичної, який забезпечує зростання врожайності на $20 \%$, призводить до того, що стовідсоткове фінансування виробничих витрат за рахунок кредиту, залученого під $19 \%$ річних, забезпечує рентабельність $67 \%$.

Звичайно, одне локальне нововведення не зможе настільки сильно вплинути на врожайність. За результатами досліджень одного з найвідоміших підприємств-оригінаторів Слобожанщини - ДП «Дослідне господарство «Елітне» Інституту рослинництва ім. В. Я. Юр'єва НААН», у разі вибору еліти замість першої репродукції приріст урожайності не перевищує 4-5\%. Водночас, за даними офіційного сайта цього підприємства, насіння озимих зернових першої репродукції та еліти на початок червня 2020 р. коштувало відповідно 6,5 і 7,5 тис. грн/т (табл. 4).

Таблиця 4

Ціна та потенційна врожайність насіння озимої пшениці пропонованого до продажу ДП «ДГ «Елітне» Інституту рослинництва ім. В. Я. Юр'єва НААН» (станом на 03.06.2020 р.)

\begin{tabular}{|c|c|c|c|c|c|}
\hline \multirow{2}{*}{ Назва сорту } & \multirow{2}{*}{ Оригінатор } & \multirow{2}{*}{$\begin{array}{c}\text { Потенційна } \\
\text { урожайність, } \\
\text { т/га }\end{array}$} & \multirow{2}{*}{$\begin{array}{l}\text { Очікуваний } \\
\text { приріст } \\
\text { урожайності, } \\
\text { т/га }\end{array}$} & \multicolumn{2}{|c|}{$\begin{array}{c}\text { Ціна, } \\
\text { тис. грн/т }\end{array}$} \\
\hline & & & & $\begin{array}{l}\text { I репро- } \\
\text { дукція }\end{array}$ & еліта \\
\hline Богдана & ІФРГ НАНУ (м. Київ) & 9,8 & 3,8 & 6,50 & 7,50 \\
\hline Запашна & $\begin{array}{l}\text { IP ім. В. Я. Юр’єва } \\
\text { НАAН (м. Харків) }\end{array}$ & 11,0 & 5,0 & 6,50 & 7,50 \\
\hline Здобна & $\begin{array}{l}\text { IP ім. В. Я. Юр’єва } \\
\text { НАAН (м. Харків) }\end{array}$ & 10,0 & 4,0 & 6,50 & 7,50 \\
\hline Малинівка & ІФРГ НАНУ (м. Київ) & 11,1 & 5,1 & 6,50 & 7,50 \\
\hline Подолянка & ІФРГ НАНУ (м. Київ) & $6,5-8,7$ & $0,5-2,7$ & 6,50 & 7,50 \\
\hline Приваблива & $\begin{array}{l}\text { IP ім. В. Я. Юр’єва } \\
\text { НААН (м. Харків) }\end{array}$ & 11,0 & 5,0 & 6,50 & 7,50 \\
\hline Розкішна & $\begin{array}{l}\text { IP ім. В. Я. Юр’єва } \\
\text { НААН (м. Харків) }\end{array}$ & $7,7-9,5$ & $1,7-3,5$ & 6,50 & 7,50 \\
\hline Славна & ІФРГ НАНУ (м. Київ) & 10,2 & 4,2 & 6,50 & 7,50 \\
\hline Смуглянка & ІФРГ НАНУ (м. Київ) & 11,5 & 5,5 & 6,50 & 7,50 \\
\hline
\end{tabular}

Джерело: упорядковано авторами на підставі $\mathrm{http}: / /$ litne.com.ua/novini/cherven2020/prajs-na-nasnnya-ozimix-kultur. 
Зважаючи на це, витрати на насіння першої репродукції та еліти становитимуть відповідно 1,3 тис. грн/га $(6,50 \cdot 0,2) \quad$ та 1,5 тис. грн/га $(7,50 \cdot 0,2)$. Таким чином, зробивши вибір на користь еліти насіння сортів Смуглянка, Богдана або Запашна, районованих для умов Лісостепу, замість його першої репродукції, сільськогосподарське підприємство, очікуючи на п’ятивідсотковий приріст урожайності, повинно буде збільшити погектарні витрати на насіння на 15,3 \% ((1,5-1,3)/1,3·100).

Установлену пропорцію вартості й результативності впровадження інновацій екстрапольовано на фактичні дані по сільськогосподарських підприємствах Харківської області за 2016-2018 рр. Зокрема, у формулі (16) ураховано, що приріст погектарних витрат на насіння $(D n)$, як і раніше, становить 0,2 тис. грн/га, але при цьому кратність приросту врожайності $(k)$ дорівнювала 1,05. Зважаючи на це, оптимуми витрат у разі їх фінансування за рахунок власних або позикових коштів дорівнюватимуть відповідно 8,3 і 7,5 тис. грн/га (табл. 5).

Таблиия 5

\section{Вплив джерел фінансування інновацій на оптимальну інтенсивність й очікувану результативність виробництва зерна пшениці сільськогосподарськими підприємствами Харківської області}

у 2016-2018 рр. (фактичні дані)

\begin{tabular}{|l|c|c|c|c|}
\hline \multicolumn{1}{|c|}{ Показник } & \multicolumn{2}{|c|}{$\begin{array}{c}\text { Фактична технологія } \\
\text { виробництва }\end{array}$} & \multicolumn{2}{|c|}{$\begin{array}{c}\text { Після переходу на } \\
\text { елітне насіння }\end{array}$} \\
\cline { 2 - 5 } & $\begin{array}{c}\text { власні } \\
\text { кошти }\end{array}$ & $\begin{array}{c}\text { позикові } \\
\text { кошти }\end{array}$ & $\begin{array}{c}\text { власні } \\
\text { кошти }\end{array}$ & $\begin{array}{c}\text { позикові } \\
\text { кошти }\end{array}$ \\
\hline Прибутковий оптимум витрат, тис. грн/га & 8,0 & 7,1 & 8,3 & 7,5 \\
\hline $\begin{array}{l}\text { Урожайність при витратах на рівні } \\
\text { прибуткового оптимуму, ц/га }\end{array}$ & 40,1 & 37,3 & 43,2 & 40,2 \\
\hline $\begin{array}{l}\text { Прибуток при витратах на рівні } \\
\text { прибуткового оптимуму, тис. грн/га } \\
\text { за умов самофінансування }\end{array}$ & 4,63 & $\mathrm{X}$ & 5,14 & $\mathrm{X}$ \\
\hline $\begin{array}{l}\text { фінансування за рахунок позикових } \\
\text { коштів }\end{array}$ & $\mathrm{X}$ & 3,20 & $\mathrm{X}$ & 3,64 \\
\hline
\end{tabular}

Джерело: результати власних розрахунків авторів.

Аналіз результатів моделювання свідчить, що, порівняно 3 контролем, у разі самофінансування витрат їх оптимум має підвищитися на 300 грн/га, що забезпечить зростання прибутковості виробництва на 510 грн/га. Натомість, залучаючи для фінансування витрат позикові кошти під 19,0\% річних, сільськогосподарське підприємство має орієнтуватися на оптимум витрат нижчий на 6,3\%. При цьому спостерігатиметься зниження прибутковості виробництва і збуту зерна пшениці на $21,4 \%$. Останнє свідчить про високу ризикованість залучення позикових коштів для фінансування впровадження технологічних інновацій. Отже, ураховуючи традиційні підходи до оцінки доцільності інвестицій, залучення позикових коштів для фінансування виробництва $\epsilon$ недоречним. Однак нелінійність взаємозв'язку витратних i 


\section{Agricultural and Resource Economics: International Scientific E-Journal}

http://are-journal.com

результативних показників у рослинництві специфічно впливає на окупність інвестицій у цю галузь, що ставить під сумнів зроблений вище висновок.

Припустимо, що підприємство не має власних обігових коштів і залучає кредит з розрахунку на гектар посівів на рівні прибуткового оптимуму 7,5 тис. грн/га - для умов змішаного фінансування. Прибуток на 1 га становитиме 3,64 тис. грн, що на 1,34 тис. грн/га менше аналогічного показника під час застосування технології 3 аналогічними виробничими витратами, фінансованими за рахунок власних коштів (табл. 6). Хоча прибуток за умов стовідсоткового кредитного покриття витрат і $\epsilon$ меншим від аналогічного показника без залучення кредиту, але i в першому, i в другому випадку фінансовий результат є позитивним, що уможливлює застосування обох варіантів фінансування виробництва та інноваційних змін у ньому.

Таблиця 6

Вплив структури джерел фінансування інновацій на прибутковість виробництва та збуту зерна пшениці сільськогосподарськими підприсмствами Харківської області у 2016-2018 рр.

\begin{tabular}{|c|c|c|c|c|c|c|}
\hline \multirow{2}{*}{ Показник } & \multicolumn{6}{|c|}{ Питомі виробничі витрати, тис. грн/га } \\
\hline & 1,5 & 3,5 & 5,5 & 7,5 & 8,4 & 9,5 \\
\hline \multicolumn{7}{|c|}{ Самофінансування } \\
\hline $\begin{array}{l}\text { Склад виробничих витрат за джерелами } \\
\text { фінансування, тис. грн/га } \\
\text { власні обігові кошті }\end{array}$ & 1,5 & 3,5 & 5,5 & 7,5 & 8,4 & 9,5 \\
\hline позикові кошти & - & - & - & - & - & - \\
\hline Прибуток (збиток), тис. грн/га & $-0,11$ & 2,45 & 4,14 & 4,98 & 5,07 & 4,94 \\
\hline \multicolumn{7}{|c|}{ Власні обігові кошти $-5,5$ тис. грн/га } \\
\hline $\begin{array}{l}\text { Склад виробничих витрат за джерелами } \\
\text { фінансування, тис. грн/га } \\
\text { власні обігові кошті }\end{array}$ & 1,5 & 3,5 & 5,5 & 5,5 & 5,5 & 5,5 \\
\hline позикові кошти & - & - & - & 2,0 & 2,4 & 3,5 \\
\hline Прибуток (збиток), тис. грн/га & $-0,11$ & 2,45 & 4,14 & 4,60 & 4,52 & 4,37 \\
\hline \multicolumn{7}{|c|}{ Власні обігові кошти $-1,5$ тис. грн/га } \\
\hline $\begin{array}{l}\text { Склад виробничих витрат за джерелами } \\
\text { фінансування, тис. грн/га } \\
\text { власні обігові кошті }\end{array}$ & 1,5 & 1,5 & 1,5 & 1,5 & 1,5 & 1,5 \\
\hline позикові кошти & - & 2,0 & 4,0 & 6,0 & 6,9 & 8,0 \\
\hline Прибуток (збиток), тис. грн/га & $-0,11$ & 2,07 & 3,38 & 3,84 & 3,76 & 3,42 \\
\hline \multicolumn{7}{|c|}{ Власні обігові кошти відсутні } \\
\hline $\begin{array}{l}\text { Склад виробничих витрат за джерелами } \\
\text { фінансування, тис. грн/га } \\
\text { власні обігові кошті }\end{array}$ & - & - & - & - & - & - \\
\hline позикові кошти & 1,5 & 3,5 & 5,5 & 7,5 & 8,4 & 9,5 \\
\hline Прибуток (збиток), тис. грн/га & $-0,40$ & 1,78 & 3,10 & 3,55 & 3,47 & 3,14 \\
\hline
\end{tabular}

Джерело: результати власних розрахунків авторів.

Заслуговує на увагу вплив залучення кредиту під оновлення технології виробництва продукції рослинництва, яке підпорядковується дії закону спадної віддачі, при різних величинах власних обігових коштів. Зокрема, якщо їх обсяг 
обмежує виробничі витрати позначкою 5,5 тис. грн/га, прибуток на 1 га дорівнюватиме 4,14 тис. грн. Залучивши кредит 3 розрахунку 2,0 тис. грн/га, сільськогосподарське підприємство зможе підвищити показник витрат до прибуткового оптимуму - 7,5 тис. грн/га, а його прибуток досягне 4,60 тис. грн/га. Отже, залучення кредиту 3 розрахунку 2,0 тис. грн/га призведе до підвищення прибутковості на 460 грн/га, унаслідок чого рентабельність інвестицій в оновлення технології дорівнюватиме 23,0\%. Проте, якщо власні джерела фінансування обмежують виробничі витрати позначкою 1,5 тис. грн/га, фінансовий результат на 1 га дорівнює 0,11 тис. грн/га. Залучивши кредит 3 розрахунку 6,0 тис. грн/га, підприємство зможе вийти на прибутковий оптимуму витрат, а його прибуток досягне 3,84 тис. грн/га.

Таким чином, залучення інвестицій під оновлення технології в обсязі 6,0 тис. грн/га сприятиме зростанню фінансового результату на 3950 грн/га; ураховуючи це, їх рентабельність становитиме $65,8 \%$. Отже, чим меншою $\epsilon$ частка власних джерел фінансування, тим більшим буде приріст прибутку за умов залучення кредиту i вищою окупність інвестиційних вкладень у впровадження технологічних інновацій.

Висновки. Кризові явища в економіці, зростання попиту на продукти харчування зумовлюють дедалі ширше впровадження агроінновацій. Це, у свою чергу, спричиняє зростання потреби у фінансових ресурсах для забезпечення цього процесу. Водночас, зважаючи на волатильність результативності інноваційного процесу, нестійкість фінансового стану багатьох сільськогосподарських підприємств, залучення фінансових ресурсів на умовах позики для інвестування в новітні сорти й гібриди є доцільним лише за умов дотримання оптимальних величин витрат. Розроблений підхід, який ураховує агробіологічні, економічні та фінансові аспекти аграрної галузі, дозволяє ще на етапі планування виробничого процесу та його фінансового забезпечення оцінити доречність кредитного покриття витрат на впровадження інноваційного рішення. У свою чергу, апробований методичний інструментарій дозволяє визначити оптимальні величини витрат за різних умов і форм фінансування, а також оптимальну величину кредитного забезпечення, що гарантує максимізацію прибутку з урахуванням очікуваного приросту врожайності за рахунок упровадження нових сортів і гібридів. Зокрема, за умов, якщо обсяг власних фінансових ресурсів сільськогосподарського підприємства в досліджуваному періоді обмежує виробничі витрати позначкою 5,5 тис. грн/га, залучення кредиту 2,0 тис. грн/га дозволяє підвищити прибуток до 4,60 тис. грн/га. 3 іншого боку, якщо власні джерела фінансування обмежують виробничі витрати позначкою 1,5 тис. грн/га залучення кредиту 6,0 тис. грн/га дозволяє досягти прибутку 3,84 тис. грн/га. Таким чином, що меншою $є$ частка власних джерел фінансування, то більшим є приріст прибутку за умов залучення кредиту й вища окупність інвестиційних вкладень у впровадження технологічних інновацій. Одночасно відмітимо, що в перспективі значущим 3 погляду практичного застосування $\epsilon$ дослідження, спрямоване на оцінку 
ефективності витрат, фінансованих у тому числі за рахунок позикового капіталу, на провадження інновацій у сфері маркетингу, організації виробництва та збуту продукції.

\section{Список використаних джерел}

1. Asheim B., Isaksen A. Regional innovation systems: the integration of local «sticky» and global «ubiquitous» knowledge. Journal of Technology Transfer. 2002. № 27. Pp. 77-86. https://doi.org/10.1023/A:1013100704794.

2. Asheim B., Gertler M. Understanding regional innovation systems. Handbook of Innovation, eds. J. Fagerberg, D. Mowery and R. Nelson. Oxford: Oxford University Press, 2004. 656 p. https://doi.org/10.1016/j.respol.2008.12.005.

3. Brynjolfsson E., Hitt L. Beyond Computation: information technology, organizational transformation and business performance. Journal of Economic Perspectives. 2000. Vol. 14. No. 4. Pp. 23-48. https://doi.org/10.1257/jep.14.4.23.

4. Cooke P. Regional innovation systems: competitive regulation in the new Europe. Geoforum. 1992. Vol. 23. Is. 3. Pp. 365-382. https://doi.org/10.1016/00167185(92)90048-9.

5. Cooke P., Morgan K. The associational economy: firms, regions and innovation. New York: Oxford University Press, 1998. 248 p. https://doi.org/10.1093/acprof:oso/9780198290186.001.0001.

6. Dahlman C., Nelson R. Social absorption capability, national innovation systems and economic development. Social Capability and Long Term Economic Growth. London: Palgrave Macmillan UK, $1995 . \quad$ Pp. 82-122. https://doi.org/10.1007/978-1-349-13512-7_5.

7. Nelson R. R. National innovation systems: a comparative analysis, 1 st ed. New York: Oxford University Press, 1993. 541 p.

8. Edquist C. Systems of innovation for development. Background paper for Chapter 1: "Competitiveness, Innovation and Learning: Analytical Framework» for the UNIDO World Industrial Development Report (WIDR). 2001. Pp. 142-148. URL: http://citeseerx.ist.psu.edu/viewdoc/download?doi=10.1.1.202.3765\&rep=rep1\&type $=$ pdf.

9. Edquist C. Systems of innovation: technologies, institutions and organizations. London: Pinter Publisher Ltd., 1997. 432 p.

10. Freeman C. Technology policy and economic performance: lessons from Japan. London: Pinter Publisher Ltd., 1987. 155 p.

11. Gu S. Implications of national innovation systems for developing countries: managing change and complexity in economic development. Discussion Paper Serie № 9903. Maastricht: United Nations University, Institute for New Technologies, 1993. $76 \mathrm{p}$.

12. Lundvall B.-A. National systems of innovation: towards a theory of innovation and interactive learning. London: Pinter Publishers, 1992. 342 p.

13. Babenko V., Nazarenko O., Nazarenko I., Mandych O., Krutko M. Aspects of program control over technological innovations with consideration of risks. Eastern-European Journal of Enterprise Technologies. 2018. Vol. 3. № 4(93). Pp. 9- 
14. https://doi.org/10.15587/1729-4061.2018.133603.

14. Asante-Addo C., Mockshell J., Zeller M., Siddig K., Egyir I. Agricultural credit provision: what really determines farmers' participation and credit rationing? Agricultural Finance Review. 2017. Vol.77. Is. 2. Pp. 239-256. https://doi.org/10.1108/AFR-02-2016-0010.

15. Baráth L., Fertő I., Bojnec Š. The effect of investment, LFA and agri-environmental subsidies on the components of total factor productivity: the case of Slovenian farms. Agricultural Economics. 2020. Vol. 71. Is. 3. Pp. 853-876. https://doi.org/10.1111/1477-9552.12374.

16. Czubak W., Pawłowski P. Sustainable economic development of farms in Central and Eastern European countries driven by pro-investment mechanisms of the common agricultural policy. Agriculture. 2020. Vol. 10. Is. 4. Pp. 93-104. https://doi.org/10.3390/agriculture10040093.

17. Garrone M., Emmers D., Lee H, Olper A., Swinnen J. Subsidies and agricultural productivity in the EU. Agricultural Economics. 2019. Vol. 50. Is. 6. Pp. 803-817. https://doi.org/10.1111/agec.12526.

18. Hadrich J., Janzen J., Etienne X., Yeager E. Agricultural credit and the changing landscape of American agriculture. Agricultural Finance Review. 2018. Vol. 78. Is. 4. Pp. 394-395. https://doi.org/10.1108/AFR-08-2018-100.

19. Islam I., Nielsen M., Ehlers B., Zaman B., Theilade I. Are trade credits a gain or a drain? Power in the sale of feed to pangasius and tilapia farmers in Bangladesh. Aquaculture Economics \& Management. 2020. Vol. 24. Is. 3. Pp. 338354. https://doi.org/10.1080/13657305.2020.1729896.

20. Kravčáková Vozárová I., Kotulič R., Vavrek R. Assessing impacts of CAP subsidies on financial performance of enterprises in Slovak Republic. Sustainability. 2020. Vol. 12(3). 948. https://doi.org/10.3390/su12030948.

21. Long L., Thap L., Hoai N. An application of data envelopment analysis with the double bootstrapping technique to analyze cost and technical efficiency in aquaculture: do credit constraints matter? Aquaculture. 2020. Vol. 525. 735290. https://doi.org/10.1016/j.aquaculture.2020.735290.

22. Mitra S., Khan M., Nielsen R. Credit constraints and aquaculture productivity. Aquaculture Economics \& Management. 2019. Vol. 23. Is. 4. Pp. 410427. https://doi.org/10.1080/13657305.2019.1641571.

23. Römer U., Musshoff O. Can agricultural credit scoring for microfinance institutions be implemented and improved by weather data? Agricultural Finance Review. 2018. Vol. 78. No. 1. Pp. 83-97. https://doi.org/10.1108/AFR-11-2016-0082.

24. Weber R., Musshoff O. Can flexible agricultural microfinance loans limit the repayment risk of low diversified farmers? Agricultural Economics. 2017. Vol. 48. Is. 5. Pp. 537-548. https://doi.org/10.1111/agec.12355.

25. Turvey C. Historical developments in agricultural finance and the genesis of America's farm credit system. Agricultural Finance Review. 2017. Vol. 77. No. 1. Pp. 4-21. https://doi.org/10.1108/AFR-09-2016-0076.

26. Вовчак О. Д., Гальків Л. І., Демчишин М. Я. Стан і проблеми розвитку 
Agricultural and Resource Economics: International Scientific E-Journal http://are-journal.com

банківського кредитування сільськогосподарських підприємств України. Фінансово-кредитна діяльність: проблеми теорії та практики. 2018. Т. 3. № 26. C. 29-37. https://doi.org/10.18371/fcaptp.v3i26.143846.

27. Hafurova O. V., Yermolenko V. M., Yermolenko I. M. Crediting to agricultural commodity producers: economic and legal problems. Financial and credit activity: problems of theory and practice. 2018. Vol. 4. No. 27. Pp. 14-21. https://doi.org/10.18371/fcaptp.v4i27.153967.

28. Думанська I. Ю. Банківське кредитування в системі фінансового забезпечення інноваційного процесу АПК. Фінансово-кредитна діяльність: проблеми теорії та практики. 2018. Т. 2 . № 25. С. 17-26. https://doi.org/10.18371/fcaptp.v2i25.135975.

29. Катан Л. І. Небанківське кредитування: особливості застосування у діяльності сільськогосподарських підприємств. Науковий вісник Ужгородського національного університету. Сер. «Міжнародні економічні відносини та світове господарство». 2018. Вип. 19. Ч. 2. С. 24-28.

30. Непочатенко O.О., Бечко П. К., Попиченко Д. А. Короткострокове кредитування сільськогосподарських підприємств під оборотні активи. Збірник наукових праць Уманського національного університету садівництва. 2016. Вип. 89. Ч. 2. С. 7-19.

31. Олійник-Данн О. О., Левкович М. П. Оцінка кредитного раціонування аграрних підприємств України. Науковий вісник Міжнародного гуманітарного університету. Сер. «Економіка і менеджмент». 2017. Вип. 24(2). С. 49-53.

32. Горох О. В., Макогон В. В., Брік С. В. Методичні підходи до визначення оптимального рівня кредитного забезпечення операційних витрат рослинництва. Економіка. Фінанси. Менеджмент: актуальні питання науки $i$ практики. 2019. № 7. C. 104-111. https://doi.org/10.37128/2411-4413-2019-7-12.

33. Мазоренко Д. І., Мазнєв Г.Є., Тіщенко Л. М., Бобловський О. Ю., Гаврилович Н. Ю. Інноваційні агротехнології; за ред. Д. І. Мазоренка, Г. Є. Мазнєва. Харків: ХНТУСГ, 2007. 385 с.

\section{References}

1. Asheim, B. and Isaksen, A. (2002), Regional innovation systems: the integration of local «sticky» and global «ubiquitous» knowledge. Journal of Technology Transfer, vol. 27, pp. 77-86. https://doi.org/10.1023/A:1013100704794.

2. Asheim, B. and Gertler, M. (2004), Understanding regional innovation systems in Handbook of Innovation, eds. J. Fagerberg, D. Mowery and R. Nelson. Oxford University Press, Oxford, UK. https://doi.org/10.1016/j.respol.2008.12.005.

3. Brynjolfsson, E. and Hitt, L. M. (2000), Beyond Computation: information technology, organizational transformation and business performance. Journal of Economic Perspectives, vol. 14, no. 4, pp. 23-48. https://doi.org/10.1257/jep.14.4.23.

4. Cooke, P. (1992), Regional innovation systems: competitive regulation in the New Europe. Geoforum, vol. 23, is. 3, pp. 365-382. https://doi.org/10.1016/00167185(92)90048-9. 


\section{Agricultural and Resource Economics: International Scientific E-Journal}

http://are-journal.com

5. Cooke, P. and Morgan, K. (1998), The associational economy: firms, regions and innovation. Oxford University Press, New York, USA.

6. Dahlman, C. and Nelson, R. (1995), Social absorption capability, national innovation systems and economic development in Social Capability and Long Term Economic Growth, Palgrave Macmillan, London, UK.

7. Nelson, R. (1993), National innovation systems: a comparative analysis, 1 st ed. Oxford University Press, New York, USA.

8. Edquist, C. (2001), Systems of innovation for development in Background paper for Chapter 1: «Competitiveness, innovation and learning: analytical framework» for the UNIDO World Industrial Development Report (WIDR), available at: http://citeseerx.ist.psu.edu/viewdoc/download?doi=10.1.1.202.3765\&rep=rep1\&type $=$ pdf.

9. Edquist, C. (1997), Systems of innovation: technologies, institutions and organizations. Pinter Publisher Ltd., London, UK.

10. Freeman, C. (1987), Technology Policy and Economic Performance: Lessons from Japan. Pinter Publisher Ltd., London, UK.

11. Gu, S. (1999), Implications of national innovation systems for developing countries: managing change and complexity in economic development. Discussion Paper Serie No. 9903. United Nations University, Institute for New Technologies, Maastricht, Netherlands.

12. Lundvall, B.-A. (1992), National systems of innovation: towards a theory of innovation and interactive learning. Pinter Publisher Ltd., London, UK.

13. Babenko, V., Nazarenko, O., Nazarenko, I., Mandych, O. and Krutko, M. (2018), Aspects of program control over technological innovations with consideration of risks. Eastern-European Journal of Enterprise Technologies, vol. 3, no. 4(93), pp. 9-14. https://doi.org/10.15587/1729-4061.2018.133603.

14. Asante-Addo, C., Mockshell, J., Zeller, M., Siddig, K. and Egyir, I. (2017), Agricultural credit provision: what really determines farmers' participation and credit rationing? Agricultural Finance Review, vol. 77, is. 2, pp. 239-256. https://doi.org/10.1108/AFR-02-2016-0010.

15. Baráth, L., Fertö, I. and Bojnec, Š. (2020), The effect of investment, LFA and agri-environmental subsidies on the components of total factor productivity: the case of Slovenian farms. Agricultural Economics, vol. 71, is. 3, pp. 853-876. https://doi.org/10.1111/1477-9552.12374.

16. Czubak, W. and Pawłowski, P. (2020), Sustainable economic development of farms in Central and Eastern European countries driven by pro-investment mechanisms of the common agricultural policy. Agriculture, vol. 10, is. 4, pp. 93104. https://doi.org/10.3390/agriculture10040093.

17. Garrone, M., Emmers, D., Lee, H., Olper, A. and Swinnen, J. (2019), Subsidies and agricultural productivity in the EU. Agricultural Economics, vol. 50, is. 6, pp. 803-817. https://doi.org/10.1111/agec.12526.

18. Hadrich, J., Janzen, J., Etienne, X. and Yeager, E. (2018), Agricultural credit 
and the changing landscape of American agriculture. Agricultural Finance Review, vol. 78, is. 4, pp. 394-395. https://doi.org/10.1108/AFR-08-2018-100.

19. Islam, I., Nielsen, M., Ehlers, B., Zaman, B. and Theilade, I. (2020), Are trade credits a gain or a drain? Power in the sale of feed to pangasius and tilapia farmers in Bangladesh. Aquaculture Economics \& Management, vol. 24, is. 3, pp. 338-354. https://doi.org/10.1080/13657305.2020.1729896.

20. Kravčáková Vozárová, I., Kotulič, R. and Vavrek, R. (2020), Assessing impacts of CAP subsidies on financial performance of enterprises in Slovak Republic. Sustainability, vol. 12(3), 948. https://doi.org/10.3390/su12030948.

21. Long, L., Thap, L. and Hoai, N. (2020), An application of data envelopment analysis with the double bootstrapping technique to analyze cost and technical efficiency in aquaculture: do credit constraints matter? Aquaculture, vol. 525, 735290. https://doi.org/10.1016/j.aquaculture.2020.735290.

22. Mitra, S., Khan, M. and Nielsen, R. (2019), Credit constraints and aquaculture productivity. Aquaculture Economics \& Management, vol. 23, is. 4, pp. 410-427. https://doi.org/10.1080/13657305.2019.1641571.

23. Römer, U. and Musshoff, O. (2018), Can agricultural credit scoring for microfinance institutions be implemented and improved by weather data? Agricultural Finance Review, vol. 78, no. 1, pp. 83-97. https://doi.org/10.1108/AFR11-2016-0082.

24. Weber, R. and Musshoff, O. (2017), Can flexible agricultural microfinance loans limit the repayment risk of low diversified farmers? Agricultural Economics, vol. 48, is. 5, pp. 537-548. https://doi.org/10.1111/agec.12355.

25. Turvey, C. (2017), Historical developments in agricultural finance and the genesis of America's farm credit system. Agricultural Finance Review, vol. 77, no. 1, pp. 4-21. https://doi.org/10.1108/AFR-09-2016-0076.

26. Vovchak, O. D., Halkiv, L. I. and Demchyshyn, M. Ya. (2018), The condition and problems of Ukraine's agricultural enterprises banking crediting development. Financial and credit activity: problems of theory and practice, vol. 3, no. 6, pp. 29-37. https://doi.org/10.18371/fcaptp.v3i26.143846.

27. Hafurova, O. V., Yermolenko, V. M. and Yermolenko, I. M. (2018), Crediting to agricultural commodity producers: economic and legal problems. Financial and credit activity: problems of theory and practice, vol. 4, no. 7, pp. 1421. https://doi.org/10.18371/fcaptp.v4i27.153967.

28. Dumanska, I. Yu. (2018), Banking lending in the system of financial providing innovative process of AIC. Financial and credit activity: problems of theory and practice, vol. 2, no. 25, pp. 17-26. https://doi.org/10.18371/fcaptp.v2i25.135975.

29. Katan, L. I. (2018), Non-bank credit: features of application in activity of agricultural enterprises. Naukovyy visnyk Uzhhorods'koho natsional'noho universytetu. Ser. "Mizhnarodni ekonomichni vidnosyny ta svitove hospodarstvo», vol. 19, part 2, pp. 24-28.

30. Nepochatenko, O. O., Bechko, P. K. and Popychenko, D. A. (2016), Short- 
term lending to agricultural enterprises under current assets. Zbirnyk naukovykh prats' Umans'koho natsional'noho universytetu sadivnytstva, vol. 89, part 2, pp. 7-19.

31. Oliynyk-Dann, O. O. and Levkovych, M. P. (2017), The credit rationing evaluation of agricultural enterprises in Ukraine. Naukovyy visnyk Mizhnarodnoho humanitarnoho universytetu. Ser. «Ekonomika i menedzhment», vol. 24, is. 2, pp. 4953.

32. Horokh, O. V., Makohon, V. V and Brik, S. V. (2019), Methodical approaches to determining the optimal level of credit security of operating costs of crop production. Ekonomika. Finansy. Menedzhment: aktual'ni pytannya nauky $i$ praktyky, no. 7, pp. 104-111. https://doi.org/10.37128/2411-4413-2019-7-12.

33. Mazorenko, D. I., Maznyev, H. Ye., Tishchenko, L. M., Boblovskyy, O. Yu. and Havrylovych, N. Yu. (2007), Innovatsiyni ahrotekhnolohiyi [Innovative agricultural technologies], KhNTUSG, Kharkiv, Ukraine.

How to cite this article? Як цитувати цю статтю?

Стиль-ДСТУ:

Олійник О., Макогон В., Міщенко В., Брік С. Ефективність витрат на впровадження нових сортів і гібридів у рослинництві. Agricultural and Resource Economics. 2020. Vol. 6. No. 4. Pp. 168-186. URL: https://are-journal.com.

Style-Harvard:

Oliynyk, O., Makohon, V., Mishchenko, V. and Brik, S. (2020), Cost efficiency for implementation of new varieties and hybrids in plant growing. Agricultural and Resource Economics, vol. 6, no. 4, pp. 168-186, available at: https://are-journal.com. 